Int. J. Odontostomat., 7(3):475-481, 2013.

\title{
Retrieval of Fractured Files Based on Electrochemical Dissolution
}

\author{
Retiro de Limas Fracturadas Basado en la Disolución Electroquímica
}

\author{
Raúl Alcántara Dufeu*; Carlos Peña Farfal ${ }^{\star *}$ \& Mónica Álvarez Muñoz ${ }^{\star \star \star}$
}

\begin{abstract}
ALCÁNTARA, D. R.; PEÑA, F. C. \& ÁLVAREZ, M. M. Retrieval of fractured files based on electrochemical dissolution. Int. J. Odontostomat., 7(3):475-481, 2013.

ABSTRACT: The purpose of this study was to investigate whether the Electrochemical Dissolution (DE) facilitates the retrieval of fractured files, from Endo-Training block with an artificial root canal, by using ultrasonic techniques (US). Twenty Endo-Training block with an artificial single canal with working length $16 \mathrm{~mm}$ and twenty nickel-titanium (NiTi) Protaper Universal rotary files were used. 10 Shaping S1 files and 10 Shaping S2 files, were sectioned transversally within the conduit, to $5 \mathrm{~mm}$ of the apical tip. Twenty samples were divided into four groups: Group1 and 3 received the action of DE and US, and groups 2 and 4 received the action of US. To remove the fragments we used Staging Platform and Dental Microscope. Outcome was analyzed statistically by Student $t$ test. Statistical Analysis showed a significant difference in retrieval time of the fragments and weight loss mass of Endo training block ultrasonic tips were used, between groups that applied Ultrasonic with electrochemical dissolution and the group using only ultrasonic. It can be concluded that there was weight loss mass of separated fragment by electrochemical action, however, it was not sufficient and its use alone was inconclusive to retrieve the fragments. The procedure needs to be complemented with the use of the staging platform, ultrasonic tips and Dental Microscope.
\end{abstract}

KEY WORDS: retrieval of fractured files, electrochemical dissolution, Nickel-Titanium, staging platform, ultrasonic tips, dental microscope.

\section{INTRODUCTION}

In the practice of Endodontic clinicians may encounter a variety of unwanted procedural accidents and obstacles to normally routine endodontic therapy (Torabinejad \& Lemon, 2002). One of these procedural problems is intracanal instrument fractured, like an endodontic files, when performing biomechanical preparation (Parashos \& Messer, 2006). It was reported that the prevalence of broken instruments of stainless steel range from 2-6\% (Hülsmann \& Schinkel, 1999), however, these files tend to be easier to remove and, in general, they do not further fracture during the removal process (Ruddle, 2004). The fractured incidence among discarded rotary NiTi files after clinical use has been reported to range from $0.39-5.0 \%$ (Nevares et al., 2012), with the overall success rate of the removal of these fragments from $55 \%$ to $79 \%$ (Shen et al., 2004). The prevalence of fractured instrument was $0.55 \%$ using stainless steel hand files instrument and $1.33 \%$ using NiTi rotary instruments (Tzanetakis et al., 2008).

The management of a case with a broken instrument may involve a three-orthograde approach to follows: to attempt to remove instrument; to attempt to bypass the instrument; and to prepare and obturate to the fractured fragment (Shen et al.). The clinician needs to balance between the advantages and disadvantages of retrieval of separated files because this could lead to the excessive removal of root dentin, which caused reduced root strength by $30 \%$ to $40 \%$ and predisposed the teeth to vertical root fracture (Alomairy, 2009). The overall success rate was found

* Chairman Endodontics Specialization Program, Department of Restorative Dentistry, Faculty of Dentistry, Universidad de Concepción, Concepción, Chile.

** Chairman of Doctorate in Science and Analytical Technology, Department of Instrumental Analysis, Faculty of Pharmacy, Universidad de Concepción, Concepción, Chile.

*** Specialist in Endodontics - 2011, Universidad de Concepción, Concepción, Chile. 
93.3\% with ultrasonics techniques and $66.6 \%$ when only conventional methods were used in curved canals (Gencoglu \& Helvacioglu, 2009). In this context, a less complex retrieval method that causes minimum damage to dental structure is necessary and the dissolution of a fractured instrument might represent an actual possibility to solve this problem. This dissolution of fractures files would enable the recovery of the original canal path without damaging the root structure (Ormiga et al., 2010). The difficulty in removing fragments and adverse prognostic of this procedural complication is a reason to consider further innovation.

The aim of this study was evaluate an electrochemical dissolution treatment in order to promote the removal of separate fragments files from simulated root canals by using ultrasonic technology.

\section{MATERIAL AND METHOD}

Twenty resin block (Endo Training Block, Densply, Maillefer) with single and artificial root canal were used. The working length was determined with a \# $10 \mathrm{~K}$ file (Dentsply Maillefer) in $16 \mathrm{~mm}$. The canal was classified into severe according to their curvature angle (Meazure program version 2.0 C Thing Software 2001-2004). Initial root canal instrumentation was prepared by stainless steel K-files \#10, \#15. Canals were irrigated with sodium hypochlorite $(3 \mathrm{ml}, 2.5 \% \mathrm{~m} / \mathrm{v})$ following each instrument. Twenty ProTaper Universal rotary instruments with variable increasing Taper (Dentsply Maillefer), with six uses, were used. Two type shaping files tested were: ten S1type (D1: 2\%; D14: 11\%; x: 0.17) and ten S2-type (D1: 4\%; D14: $11.5 \%$; $x$ : 0.20). The cut positions were selected in such a way to correspond a $5 \mathrm{~mm}$ from the tip (D5) of file (Fig. 1). Instruments were notched with a diamond polishing \#006 bur (Jota rotary instruments and NSK Pana-Max Plus), $2.5 \mathrm{~mm}$ from the tip to facilitate file fracture at a set length. With radiograph determined location in the apical one-third. They were divided into 4 groups of 5 files each, with $n=20$ : Group 1-3: Fragments S1-S2: with electrochemical treatment application and fragment removal with ultrasonic tips; Group 2-4: Fragments S1S2: without application of electrochemical treatment and removal of the fragment with Ultrasonic.

Ten Shaping Files (five S1 and five S2) were embedded of electrochemical solution. A constant potential of $3 \mathrm{~V}(\mathrm{vs}$. $\mathrm{Ag} / \mathrm{AgCl})$ was applied by means of a potentiostat (Electrochemical Analyzer, $\mathrm{CH}$ Instruments)

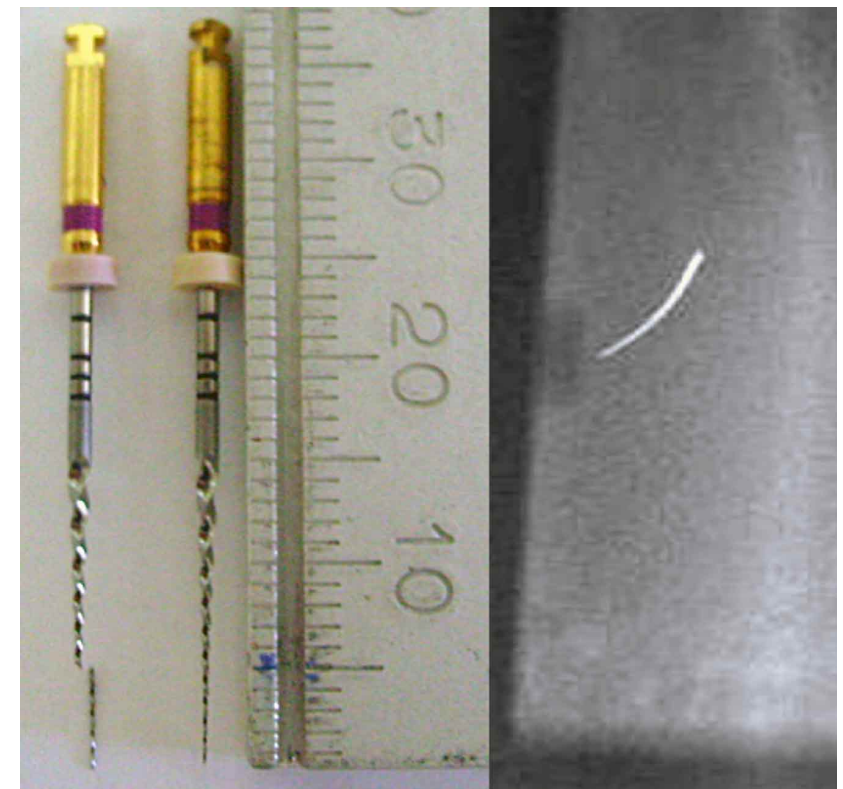

Fig. 1. Fragment of Ni Ti rotary files, S1-S2.

computer controlled. Platinum wire (diameter $0.25 \mathrm{~mm}$ ) plus segment file, was immersed $25 \mathrm{~min}$, in an electrolyte formed by $\mathrm{NaCl} 0,5 \mathrm{~g} / \mathrm{L}$ and $\mathrm{NaF} 8 \mathrm{~g} / \mathrm{L}$ dissolved in chemically pure water (Milli-Q) (Fig. 2).

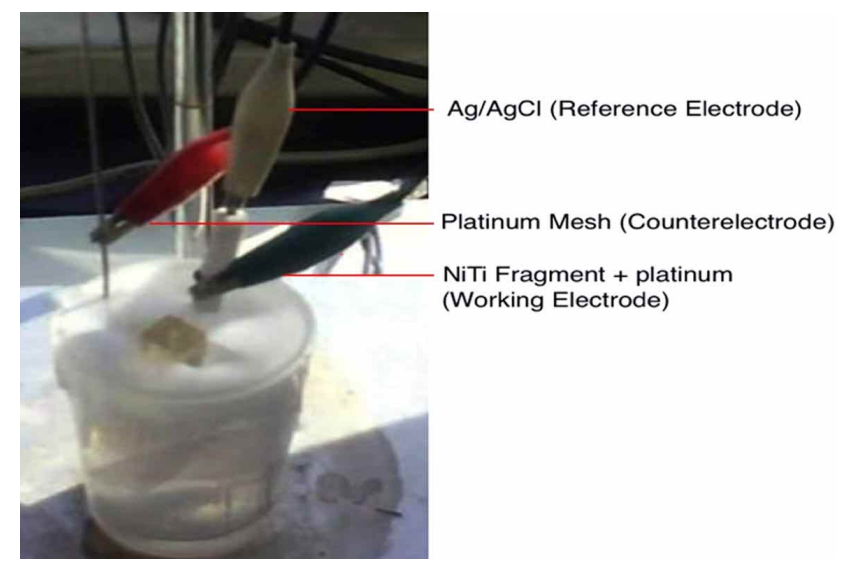

Fig. 2. Electrochemical configuration. Electrodes immersed in the solution.

An $\mathrm{Ag} / \mathrm{AgCl}$ wire was used as reference electrode, a platinum mesh as counter electrode and $\mathrm{NiTi}$ fragment with platinum as working electrode. A constant anode potential was applied to NiTi, while the potentiostat registered the anode. The total charge of each test was registered using a program of data analysis software PS Lite 1.7.3. The following graphs were obtained: current-time (A-Sec, Fig. 3) and LoadTime (Cb-Sec, Fig. 4). 

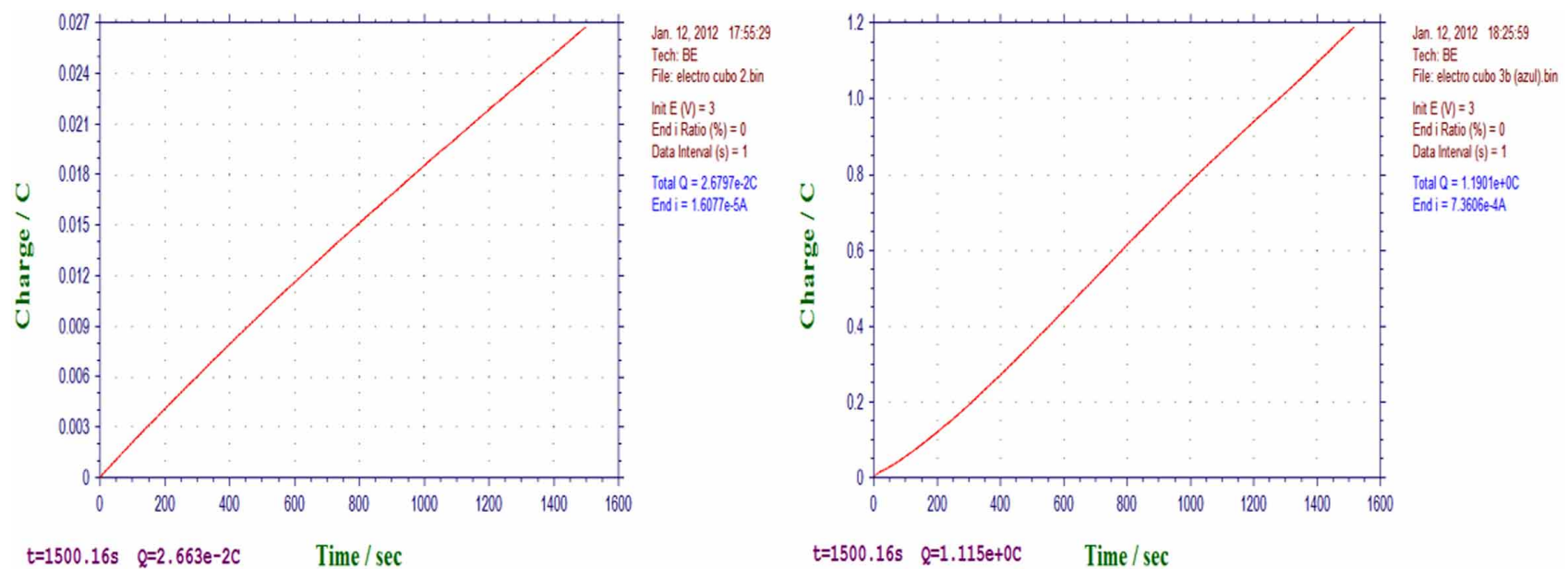

Fig. 3. Increase Linear: Loads (Cb) - Time (Sec). S1-S2 ProTaper Files.

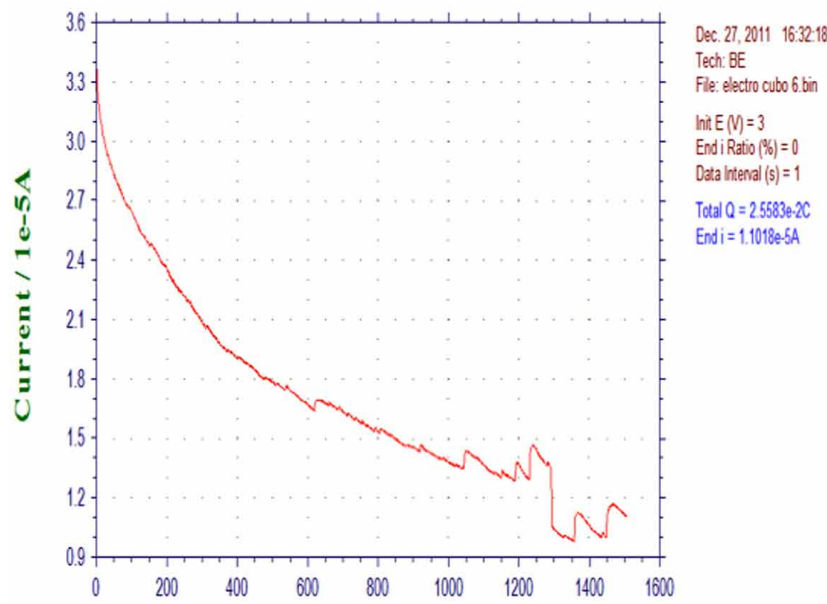

$t=1500.16 \mathrm{~s} \quad \mathrm{i}=1.109 \mathrm{e}-5 \mathrm{~A} \quad$ Time $/ \mathrm{sec}$

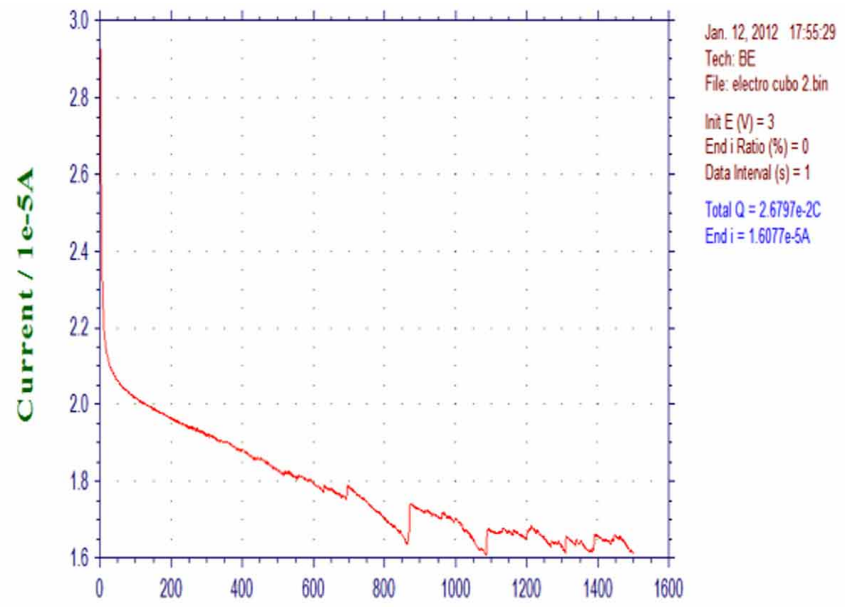

$t=1500.16 \mathrm{~s} \quad \mathrm{i}=1.608 \mathrm{e}-5 \mathrm{~A} \quad$ Time $/ \mathrm{sec}$

Fig. 4. Exponential Decay: Current (A)-Time (Sec). S1-S2 ProTaper Files

Oxidation Half-reaction of $\mathrm{Ni}$, determined with increasing the time, then amount of charge was higher, and by applied a potential to the metallic $\mathrm{Ni}$, Ni becomes dissolved. Releases electrons and these were measured like a current. Figure 3, for the group 1-3, showed which has a direct relation of load and time variables. And Figure 4, represents the loss of electrode surface corresponding to separate fragment, product of electrochemical action.
$\mathrm{Ni}^{\circ} \mathrm{fl} \mathrm{Ni}+2+2 \mathrm{e}$, Oxidation Half- reaction.

The weight loss values of $\mathrm{Ni}$ and the electrical charge generated during the test were summarized in Table I y Table II.

Results of the Implementation Electrochemistry. The procedure for retrieval of fractured files was: access cavity preparation allowing for straight-line access -Staging Platform- was performed by Gates Glidden burs (GG)

Table I. Data from System for S1 files.

\begin{tabular}{|c|c|c|c|c|c|}
\hline s1 & Load (Cb) & Current (A) & n Electrons & Mass (Mol) & Níckel (mg) \\
\hline 1 & $2.678 \times 10^{-<}$ & $1.612 \times 10^{-5}$ & $1.6 \times 10^{1 /}$ & $1.3 \times 10^{-1}$ & $7.6 \times 10^{-3}$ \\
\hline 2 & $7.115 \times 10^{-<}$ & $5.004 \times 10^{-5}$ & $4.4 \times 10^{11}$ & $3.6 \times 10^{-1}$ & $2.1 \times 10^{-<}$ \\
\hline 3 & $2.549 \times 10^{-<}$ & $1.112 \times 10^{-5}$ & $1.5 \times 10^{1 y}$ & $1.2 \times 10^{-5}$ & $1.2 \times 10^{-<}$ \\
\hline 4 & $4.198 \times 10^{-2}$ & $2.999 \times 10^{-5}$ & $2.6 \times 10^{\prime \prime}$ & $2.1 \times 10^{-1}$ & $7.0 \times 10^{-1}$ \\
\hline 5 & $1.137 \times 10^{-1}$ & $4.887 \times 10^{-5}$ & $7.0 \times 10^{11}$ & $5.8 \times 10^{-1}$ & $3.4 \times 10^{-<}$ \\
\hline
\end{tabular}


Table II. Data from system for S2 files.

\begin{tabular}{|c|c|c|c|c|c|}
\hline S2 & Load (Cb) & Current (A) & n Electrons & Mass (Mol) & Nickel (mg) \\
\hline 1 & $6.644 \times 10^{-2}$ & $4.780 \times 10^{-5}$ & $4.1 \times 10^{11}$ & $3.4 \times 10^{-1}$ & $1.9 \times 10^{-L}$ \\
\hline 2 & $2.990 \times 10^{-1}$ & $3.607 \times 10^{-4}$ & $1.8 \times 10^{10}$ & $1.4 \times 10^{-0}$ & $8.2 \times 10^{-2}$ \\
\hline 3 & 1.176 & $7.481 \times 10^{-4}$ & $7.3 \times 10^{18}$ & $6.0 \times 10^{-0}$ & $3.5 \times 10^{-1}$ \\
\hline 4 & $2.889 \times 10^{-1}$ & $5.387 \times 10^{-4}$ & $1.8 \times 10^{18}$ & $1.4 \times 10^{-0}$ & $8.2 \times 10^{-<}$ \\
\hline 5 & $1.312 \times 10^{-<}$ & $9.172 \times 10^{-0}$ & $8.1 \times 10^{10}$ & $6.7 \times 10^{-ð}$ & $3.9 \times 10^{-5}$ \\
\hline
\end{tabular}

(Dentsply, Maillefer). A size 1-4 GG was required to provide sufficient space around the file to allow the introduction of ultrasonics, which were used to enlarge the canal to a funnel shape coronal to reach the instrument fragment and allow visualization of the fractured files with operating microscope (Ruddle) (Fig. 5).

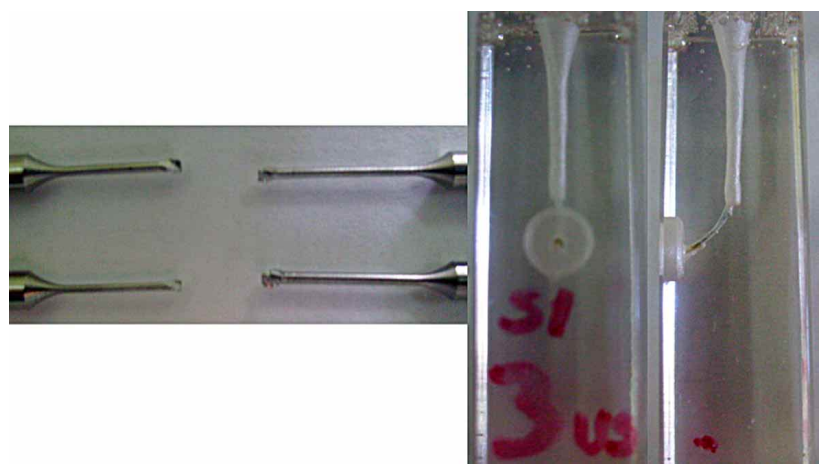

Fig. 5. Modified Gates Glidden drills and Staging Platform.

The Microscope and Ultrasonic tips \#7 (ProUltra Dentsply Maillefer and Satelec Suprasson P5), proceeded to save removal of fragment. These tips were used lightly in a counter-clockwise direction Counter-ClockWise direction, around the coronal obstruction, during $60 \mathrm{~min}$. Coronal one-third fragment was photographed with Nikon Coolpix 4500 digital camera attached with OPTO Dental microscope with $12 \mathrm{X}$ and 20X, to visualize the most coronal aspect of fragment (Fig. 6).

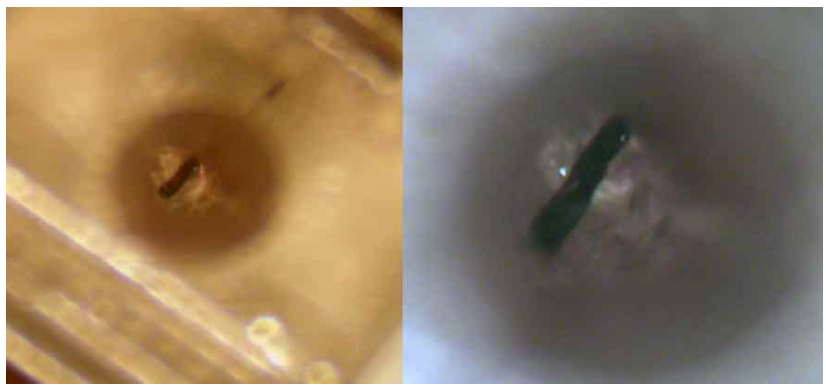

Fig. 6. Microscopic vision 12X and 20X, of coronal one-third of fragment.

The results were analyzed statistically by Student test and interpreted at a 5\% significance level.

\section{RESULTS}

The time of retrieval Fractured files by Ultrasonics Technology is show in Table III. The weight loss mass EndoTraining block values, in group 2 - 4, without electrochemical treatment, was higher compared to group 1-3, than received electrochemical treatment

The results evidence that there were a statistical difference between group1-3 and group 2-4, considering the electrochemical dissolution treatment.

Table III. Time of retrieval Fractured files by Ultrasonics Technology.

\begin{tabular}{lccccccc} 
S1 & Treatment & Retrieval & Time (min) & S2 & Treatment & Retrieval & Time (min) \\
\hline 1 & T & R & 22 & 1 & T & R & 27 \\
2 & T & UR & 60 & 2 & T & R & 54 \\
3 & T & R & 32 & 3 & T & R & 37 \\
4 & T & R & 25 & 4 & T & UR & 60 \\
5 & T & R & 43 & 5 & T & R & 53 \\
6 & UT & R & 35 & 6 & UT & UR & 60 \\
7 & UT & UR & 60 & 7 & UT & R & 43 \\
8 & UT & UR & 60 & 8 & UT & UR & 60 \\
9 & UT & UR & 60 & 9 & UT & R & 26 \\
10 & UT & UR & 60 & 10 & UT & R & 48 \\
\hline
\end{tabular}

T: Treatment; UT: Untreated; R: Retrieval; UR: Unrecovered. 


\section{Retrieval fragment wth Electrochemical Dissolution and Ultrasonic tips}

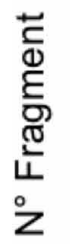

10

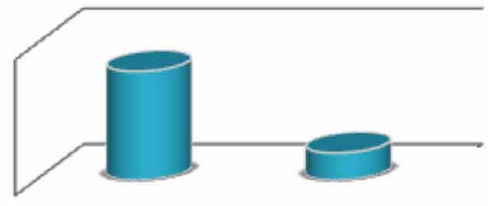

Retrieval: 8 Unrecovered: 2

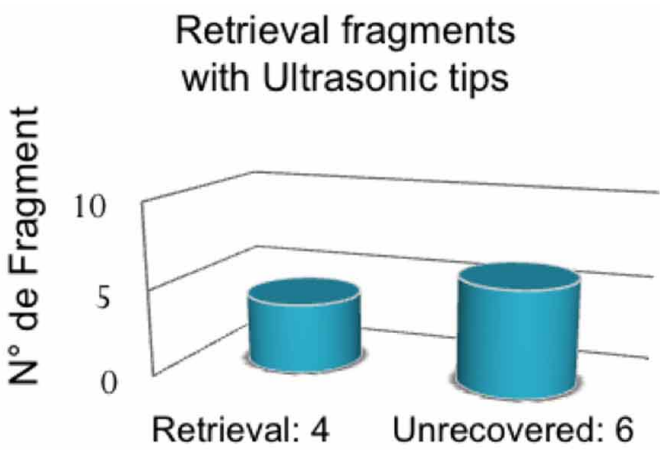

with Ultrasonic tips

Retrieval: $4 \quad$ Unrecovered: 6

Fig. 7. Graphs with number of fragments removed.

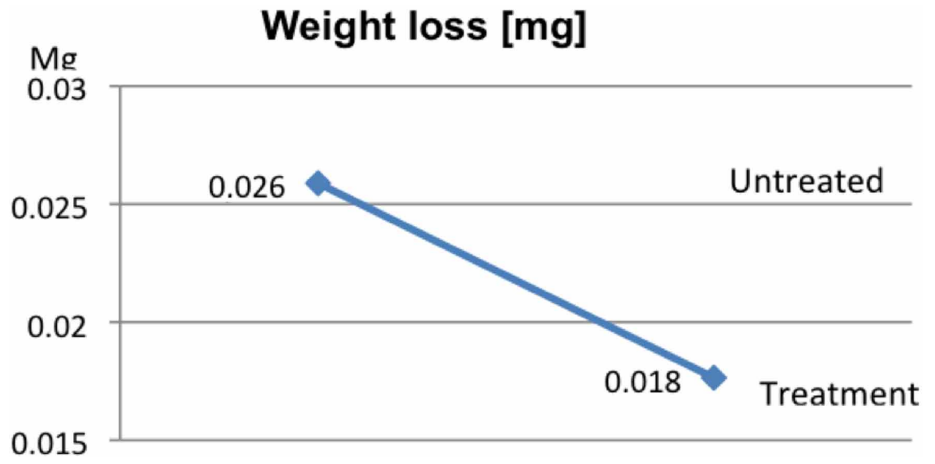

Fig. 8. Weight Loss mass EndoTraining block.

\section{Min $\quad$ Retrieval time}

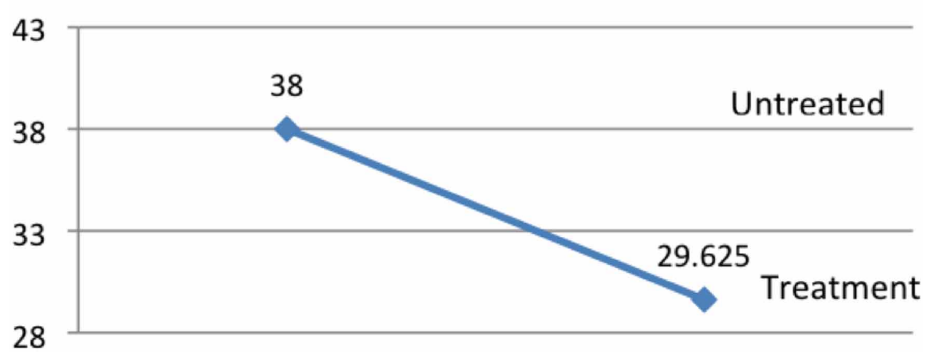

Fig. 9. Electrochemical Comparison Treatment.

\section{DISCUSSION}

Retrieval of fractured instruments by an electrochemical dissolution process is a concept that requires the presence of electrodes immersed in an electrolyte composed by sodium chloride and sodium fluoride. The working electrode has an inert platinum tip in contact with the separated fragment which must be flooded with the electrolyte. The dissolution process is slow so a difference of potential must be applied to accelerate the transfer of electrons and release metallic ions to the solution. This will reduced dissolution time of the fragment surface (Ormiga et al., 2011).

The use of aqueous solutions containing fluoride $(\mathrm{NaF} 5 \mathrm{~g} / \mathrm{L}+\mathrm{NaCl} 1 \mathrm{~g} / \mathrm{L})$ might facilitate the dissolution process of NiTi alloy (Ormiga et al., 2011). The results indicated that a concentration $\mathrm{NaF} 8 \mathrm{~g} / \mathrm{L}+\mathrm{NaCl} 0.5 \mathrm{~g} / \mathrm{L}$ for $25 \mathrm{~min}$. generated a marginal value of weight loss mass in the NiTi fractured fragment. Consequently, it is necessary to use another composition of solution to dissolve. Schiff et al. (2002) observed surface degradation of NiTi alloys in the form of localized pitting corrosion. Huang (2007) concluded that the formation of oxide protective layer does not occur at the surface of alloy of NiTi in fluoridecontaining environments. Further studies are needed to investigate these phenomena in more detail.

Ormiga et al. (2010) reported the retrieval of fractured instruments from curve canals is possible without obtaining a straight-line access to the fragment. The results presented here indicated that was essential to prepare a staging platform in the four groups, causing wear in the inner walls of the simulated canals. The weight loss mass in the Endo training block after removed the fragments was lower in the electrochemical treatment groups than the groups that only used ultrasonic, data statistically significant $(P<0.05)$. Higher dissolution can be achieved with longer application of electrolysis at the same potential or application of a greater potential for the same time, both would affect tissues surrounding the tooth by heat generation. 
In the present study the platinum tip had a 0.25 $\mathrm{mm}$ diameter; this was not the minimum possible thickness. As a result this area exposed to the solution was reduced, thus resulted marginal in weight loss of mass fragment $\mathrm{NiTi}$. This is confirmed by studies that indicated the current levels used to promote the dissolution depends on the area exposed to the solution and the diameter of the surface of fragment exposed to the medium. The larger is the diameter of the exposed surface cross section the higher is the total value of electrical charge (Ormiga et al., 2011).

The potential difference applied during 25 minutes plus 60 minutes application of ultrasonic tips is a reasonable time for its use in endodontic treatment. Staging platform were used in all the EndoTraining blocks to removed separate fragments, with ultrasonic tips to release and remove by ultrasonic waves. However, the recovered time of fragments values, was lower (29.6 min) in groups treated electrochemically than in groups where only ultrasonic treatment was applied (38 $\mathrm{min})$, the difference was significant $(P<0.05)$.

Fractured files had a tendency to straighten inside root canal curve, interlocking on the opposite wall to direction of the curve. Thus hampered rotary movement counter-clockwise is recommended to unscrew the fragment. The ultrasonic tip requires space to be used, however, excessive wearing inside the wall of root canal structure increases the risk of transport or root perforations. Also, ultrasonic vibration, could push the fragment through the apex during file removal procedure further complicating the prognosis.

Under the limitations of the present study and according to the results, we concluded that the use of electrochemical dissolution for retrieval of fractured rotary instruments in root canal had a favorable technique outcome. However, the weight loss mass of the alloy was marginal and was not enough. The electrochemical method requires use of Ultrasonic Technology and Dental Microscope. Its use alone was inconclusive to remove the fragment. Considering that sodium fluoride can be in contact with a larger surface of the fragment, the chemical concentration of the solution and the load potential to achieve effective dissolution of the fragment in a limited space such as the root canal, must continue to be researched.

ALCÁNTARA, D. R.; PEÑA, F. C. \& ÁLVAREZ, M. M. Retiro de limas fracturadas basado en la disolución electroquímica.Int. J. Odontostomat., 7(3):475-481, 2013.

RESUMEN: Este estudio tiene como propósito determinar si la Disolución Electroquímica (DE) favorece el retiro de fragmentos de limas fracturadas, insertos en bloc endodónticos de entrenamiento de resina, con un conducto radicular simulado, mediante el uso de ultrasonido (US). Se utilizaron 20 bloc y 20 limas rotatorias usadas ProTaper Universal de NiTi Shaping Files, 10 S1, 10 S2, que fueron fracturadas dentro del conducto, a $5 \mathrm{~mm}$ desde la punta apical y divididos en Grupo1 y 3 que recibieron la acción de la DE y US; y Grupo 2 y 4 sólo utilizó US. Para retirar los fragmentos se utilizó Plataforma de Trabajo y Microscopio Dental. Los datos fueron analizados con la prueba T de Student. Los resultados indican que existen diferencias estadísticamente significativas en el tiempo de retiro de los fragmentos y en la pérdida de masa del bloc de entrenamiento por el uso del ultrasonido, en los grupos que se aplicó Disolución Electroquímica más Ultrasonido. Se puede concluir que la acción electroquímica permite que exista pérdida de masa del fragmento fracturado, sin embargo, no es suficiente y su sola utilización no es concluyente para retirar los fragmentos, es necesario complementar el procedimiento con la utilización de la Plataforma de Trabajo, puntas de ultrasonido y el Microscopio Dental.

PALABRAS CLAVE: retiro de limas fracturadas, disolución electroquímica, Nickel-Titanio, plataforma de Trabajo, ultrasonido, microscopio dental.

\section{REFERENCES}

Alomairy, K. H. Evaluating Two Techniques on Removal of Fractured Rotary Nickel-Titanium Endodontic Instruments from Root Canals: An In Vitro Study. J. Endod., 35(4):55962, 2009.
Gencoglu, N. \& Helvacioglu, D. Comparison of the Different Techniques to Remove Fractured Endodontic Instruments. Eur. J. Dent., 3(3):90-95, 2009. 
Huang, H. H. Variation in surface topography of different NiTi orthodontic archwires invarious commercial fluoridecontaining environments. Dent. Mater., 23(1):24-33, 2007.

Hülsmann, M. \& Schinkel, I. Influence of several factors the success or failure of removal of fractured instruments from the root canal. Endod. Dent. Traumatol., 15(6):2528, 1999.

Nevares, G.; Cunha, R. S.; Zuolo, M. L. \& Bueno, C. E. Success Rates for Removing or Bypassing Fractured Instruments: A Prospective Clinical Study. J. Endod., 38(4):442-4, 2012.

Ormiga, F.; da Cunha Ponciano Gomes, J. A. \& de Araújo, M. C. Dissolution of nickel-titanium endodontic files via an electrochemical process: a new concept for future retrieval of fractured files in root canals. J. Endod., 36(4):717-20, 2010.

Ormiga, F.; da Cunha Ponciano Gomes, J. A.; de Araújo, M. C. \& Barbosa, A. O. An initial investigation of the electrochemical dissolution of fragments of nickel-titanium endodontic files. J. Endod., 37(4):526-30, 2011.

Parashos, P. \& Messer, H. Rotary NiTi Instrument Fracture and its Consequences. J. Endod., 32(11):1031-43, 2006.

Ruddle, C. Nonsurgical retreatment. J. Endod., 30(12):82745, 2004.

Schiff, N.; Grosgogeat, B.; Lissac, M. \& Dalard, F. Influence of fluoride content and $\mathrm{pH}$ on the corrosion resistance of titanium and its alloys. Biomaterials, 23(9):1995-2002, 2002.

Shen, Y.; Peng, B. \& Cheung, G. S. Factors associated with the removal of fractured $\mathrm{NiTi}$ instruments from root canal systems. Oral Surg. Oral Med. Oral Pathol. Oral Radiol. Endod., 98(5):605-10, 2004.

Torabinejad, M. \& Lemon, R. Procedural accidents. In: Walton, R. \& Torabinejad, M. (Ed.). Principles and practice of endodontics. Philadelphia, W.B. Saunders Company, 2010. pp.310-30.

Tzanetakis, G. N.; Kontakiotis, E. G.; Maurikou, D. V. \& Marzelou, M. P. Prevalence and Management of instrument Fracture in the Postgraduate Endodontics Program at the Dental School of Athens: A Five- year Retrospective Clinical study. J. Endod., 34(6):675-8, 2008.
Correspondence to:

Dr. Raúl Alcántara Dufeu

Departamento de Odontología Restauradora

Facultad de Odontología

Universidad de Concepción

Avda. Roosevelt 1550

Concepción

CHILE

Phone: 56-41-2243311

Email: ralcanta@udec.cl

Received: 05-12-2012

Accepted: 22-08-2013 